\title{
Doctoral Education And Government Funding In Higher Education Institutions: An Approach From Chile
}

Liliana Pedraja-Rejas, Universidad de Tarapaca, Chile

Emilio Rodriguez-Ponce, Universidad de Tarapaca, Chile

Carmen Araneda-Guirriman, Universidad de Tarapaca, Chile

\begin{abstract}
This research reveals the importance that government funding and the quality of faculty have on the doctoral training of universities from the Council of Chilean Universities (CRUCH), thus exploring the existing relationship inside this formative process. The results and conclusions show that government funding has a direct impact on doctoral training in Chile, along with the quality of the academic staff that these analyzed institutions have. Therefore, it is pertinent to conclude that fiscal funding and quality of faculty is important and relevant within the training of doctors in Chile.
\end{abstract}

Keywords: Government Funding; Quality of Faculty; Doctoral Training

\section{INTRODUCTION}

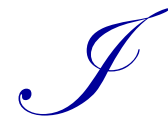

$\mathrm{n}$ recent times the number of graduates has changed, mainly since 1990, characterized by an increase in the number of women and the proportion of international students (Dobson, 2012), changing thus the composition of their graduates. Similarly, governments around the world have invested in the expansion of doctoral education (Nerad, 2010), whose programs vary considerably among others in a discipline (Altbach, 2014).

There are several reasons for the development of doctoral education, namely as increasing the number of doctoral degrees and improvement in the quality of their education (Lavonen and Krzywacki, 2014).

This increase is by the requirements of the economy of knowledge, where issues such as economic growth, construction capacity and international cooperation and competitiveness were expected. Because of this, governments have allocated significant resources to increase research funding and expand the potential of their countries (Nerad, 2010). About what was stated above, emerges one of the concerns in the training of doctors, which refers to the delay in the allocation of funds and the ever-changing strategies of the funders. Consequently, some doctoral programs have been established with external funds obtained by program leaders, but are under constant threat by changes of direction and priorities in the agencies, private donors and industry (Herman, 2011).

Moreover, there is general interest in the impact of the doctorate, mainly due to growing concern in higher education policy regarding behavior, the results and returns on investment in research. Therefore, both the government and private organizations are investing considerable time, energy and resources on identifying and tracking social and economic contributions of doctoral and research impact (Halse and Mowbray, 2011).

In this context, it becomes an important factor to have a quality academic staff in institutions with doctoral programs, because it is closely related to the quality of the programs offered in universities (Gunawardena, 2013). However, despite the fact that teachers possess the technical management in their field of activity, they might not have had the training necessary for the practice of teaching (Chen et al., 2014). 
More specifically, concerning teaching, it requires a public stance with reference to the profession and its protection, to ensure the academic practice (Avalos et al., 2010).

Indeed, the quality of academic staff is vital not only for the quality of programs and universities but also for the reputation and ranking of these institutions in the academic community (Lorange, 2006). Therefore, one way to improve the quality of teaching in higher education is given by relieving the teacher's role rather than focusing only on the organization as a whole (Chen et al., 2014).

\section{THEORETICAL FRAMEWORK}

\section{Funding of Universities and Their Impact on Doctorate}

The massification of higher education in Western Europe and other OECD countries over the past fifty years that had been considered as the most important development of tertiary education in recent times. This expansion can be attributed to human capital theory, investment and national economic growth (Alexander, 2000). Also, concerning the financing of higher education, one of the changes experienced in the universities during the last period that had been the decoupling of the United Nation (Marginson, 2013). In this sense, the pressure on public funding for tertiary education in some countries has forced higher education institutions to seek additional income.

In this context, it may be noted that in the UK, the funding system has restored an internal hierarchy, where research funds are separate from the set of resources to cover educational expenses in proportion to students. Therefore, the funding of tertiary education has become increasingly competitive, based on strict periodic evaluations, leading to a strong concentration in a small number of high-quality universities. Other universities, although formally equal in degrees and access to funding for research, are left behind in reputation and attractiveness. These differences between universities in the UK system were accepted as natural (Schubert et al., 2014).

Previously, Kehm (2009) stated that funding for doctoral requires policies aimed at two aspects: first, in financing institutions to establish and run doctoral programs, and second, on doctoral students so that they can devote adequate time to their studies. In Germany, on the other hand, the management of universities and, therefore, doctoral education, is highly decentralized in all federal states. In this way, many of these states have introduced performance-related financing based on incentive models (Schneider and Sadowski, 2010). Similarly, there is a link between research intensity and number of doctoral degrees awarded, which is related to the academic staff (Varga and Horvath, 2014).

However, many of the policy decisions that seek to downplay the public funding of higher education were taken during a period in which governments embraced the concept of massification (Alexander, 2000). In this regard, Barr (1993) argues that in terms of policy, universities can be financed in two ways, which can be given together or separately. On the one hand, delivering resources can be by a direct route, through a global grant, or by students or other actors, also claimants of education services.

In Chile, the fiscal financing granted to universities is governed by the Law of current budgets, and is more oriented to students, who get double the resources received by institutions (Comptroller General of the Republic, 2012). In this regard, the public funding does not replace private payments made in higher education (Bernasconi, 2014).

Consequently, fiscal resources (the Direct Fiscal Contribution), are available only for the universities belonging to the Council of Chilean Universities (CRUCH). It is worth noting that the CRUCH is made up of the 25 public and traditional universities in the country, which existed or derived from existing as of December 31, 1980. Through the DFL No. 4 of 1981 is determined that the State shall contribute to the financing of such universities through tax contributions whose annual amount and distribution is in accordance with these rules (DIVESUP, 2013). It should be noted that higher education in Chile, both public and private, are subject to the tuition fees, which constitute approximately $60 \%$ of its funding. Indeed, the structure of financing higher education has come to resemble that of the United States, with $40 \%$ coming from private funds, although in the case of Chile, the latter consists almost solely of tuition payments because philanthropic donations are quite restricted (Bernasconi, 2014). 


\section{Quality of Faculty and Ph.D.'s Training}

The evaluation of doctoral experience quality as preparation of teachers is complex. The above is because a significant proportion of trained doctors works outside the academia instead of becoming teachers. In turn, many doctoral students develop their work as assistant teachers, delivering part of undergraduate teaching in a typical large university (Austin, 2002). It is worth mentioning that a quarter of doctoral graduates finds work in higher education institutions or outside the University in research centers (Enders, 2005). This is relevant because just as in Australia and the rest of the developed world, Chile is in the midst of addressing associated with the age structure of its academic staff issues; also with an increasing need to improve the workforce at country level, university and faculty (Edwards and Smith, 2010). The quality of faculty, therefore, is crucial for any higher education institution achieve its mission and success (Al-Ghamdi and Malcolm, 2013). Moreover, increased funding for doctoral programs in Australia, has brought an increase in demand for academics with doctorates in Australian universities, as well as the increased enrollment of international doctoral candidates (Heaney et al., 2012).

In Latin America, countries like Colombia have experienced a significant increase in doctoral graduates in the last decade, similar to other countries in the region situation, allowing the subsequent increase in funding for doctoral training, both for increasing scholarships, and for improving the mobility of researchers and strengthening the infrastructure of doctoral programs (Acosta and Celis, 2014).

Therefore, in many countries of the world there is a constant concern to improve the quality of its faculty. In this regard, in some countries, such as Estonia, the quality of universities' academics is given by the training of these (Udam and Heidmets, 2013). This growing concern may be related to the relevance of vocational training of faculty in the accreditation processes, which are considered the foregoing, because academic staff quality is considered one of the central aspects of excellence institution of higher education (Tsiniduo et al., 2010). Furthermore, the quality of faculty is largely related with technology transfer through measures such as the number of publications in journals and the number of patents and academic endeavors (Perkmann et al., 2011).

With regard to the quality of faculty, the results of a recent study in Chile indicate that funding received by higher education institutions directly impact significantly on the quality of faculty (Araneda et al., 2013). Therefore, for Chilean higher education institutions, it is imperative to define the attraction, development and retention of top talent regarding faculty (Hax and Ugarte, 2014).

Moreover, there is evidence that teachers' quality is an important determinant of outcomes in the short and long-term doctoral students, impacting the probability that the student published the results of his dissertation in a magazine, and also the possibility that this student is a university professor (Waldinger, 2010).

Currently, the doctoral education has expanded as a way to respond to changes experienced by the labor market, the development of new disciplines and the specialization and diversity that presents the student population (Sharmini et al., 2014).

The training of doctors is vital to the economy of knowledge. In this regard, investment in the training of doctors in Australian universities has been substantial and has continued to expand rapidly. In 2000, the state government allocated about 545 million in grants for the operation of the university to support the teaching of postgraduate research students (Harman, 2002).

In 2011, the doctoral graduation patterns indicated that $1.6 \%$ of young people in OECD countries graduate from doctoral programs, compared with $1 \%$ achieved in 2000 . The countries that showed more graduation were Denmark, Ireland, New Zealand, Slovakia and the United Kingdom (OECD, 2013).

A Ph.D. (doctorate) is the certification required to do research and also to increase the stock of knowledge from which economic growth depends on ultimately (Freeman, 2010). Given the above, the degree of Doctor seeks to transform students into independent researchers, able to adapt to a variety of destinations in employment, leadership positions in academia, industry and professional performance (Manathunga et al., 2009). 
In this context, China is a case in point, where the greatest growth in the number of doctorates awarded (Freeman, 2010) was experienced, producing an estimated 117,000 doctoral graduates in 2010, more than any other nation and whose sustained increase is ten times the value obtained in 1999. This situation looks set to meet the government's goal of becoming a leader in higher education, notwithstanding the above, given that a large number of doctorates has decreased in quality (Liu and Geng, 2011).

\section{Doctoral Training in Chile}

For context, it is worth noting what is happening in Chile, where from a historical perspective, the country had never had so many surplus taxes for really significant investments in education. Therefore, the government has developed a policy of scholarships whose beneficiaries are traveling to various destinations around the world to get trained (Hax and Ugarte, 2014).

Likewise, there is evidence that for more than a decade, in several developed economies a significant number of doctoral graduates are in nonacademic jobs (Freeman, 2010). Indeed, the recognition of the importance of training of doctoral graduates in the knowledge economy implies the need for research careers go beyond the traditional academic career and generate interest in connecting with doctorates nonacademic jobs (Neumann and Tan, 2011). On the other hand, the doctorate today can be considered a education of masses, particularly due to the expansion of access roads, diversifying the student population that have access to doctoral education, therefore, the knowledge base of students is equally diverse and variable (Craswell, 2007). In this regard, it should be noted that mass production of the doctoral training includes the quality of graduates, therefore, the quality of doctoral becomes more stratified, and thus the industry is increasingly geared to institutions and programs with a quality mark to distinguish the candidates for a job (Doran and Lott, 2012).

In Chile, the doctoral training can be seen rather as a recent process in most disciplines, since for much of the time the activities of universities were linked mainly to the formation of undergraduate and may be this reason a cause of the low proportion of graduation of doctors compared to other countries (Vera-Villarroel, 2010). This coincides with the approach of the Report on Higher Education in Chile OECD (2009) where it is evident that Chile produces very few PhDs, compared to other countries, highlighting the need for more doctoral programs of quality to avoid high dependence on overseas training. Although Chile has a low production of PhDs, in recent times has been getting better results. Between 1999 and 2004 the number of doctoral graduates increased from 75 to 244 students (Thorn, 2005), showing an increase in the number of doctoral graduates to 542 in 2012 (SIES, 2014).

Note that CRUCH's universities (traditional Chilean universities) have $62.6 \%$ of graduate students, of whom $89.2 \%$ are Ph.D. students (OECD, 2009).

According to the mentioned above, the hypothesis proposed by the research is stated below:

Hypothesis 1: the relationship between funding received by universities and Ph.D. graduates who manage is mediated by the quality of faculty that they possess.

The relationship suggested in this hypothesis can be seen in the scheme of Figure 1.

Figure 1. Theoretical model research

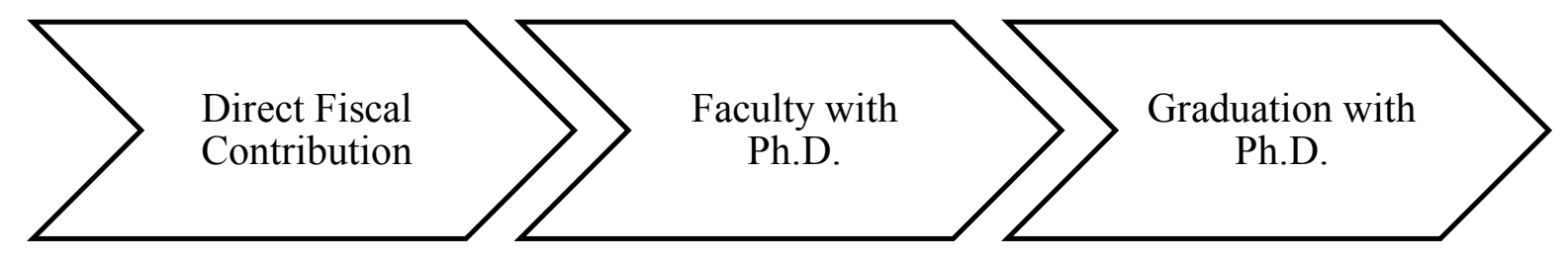




\section{METHODOLOGY}

The research methodology is a quantitative type and descriptive order. The source of information used in the research is of secondary order obtained from the report Fiscal Financing Higher Education 2011 General Accounting Office (2012) and the Statistical Yearbook 2011 of the Council of Rectors of Chilean Universities.

The sample was the 25 universities that are part of the Chilean Traditional Universities (CRUCH).

The variables used in the study and the source of information from which the data were obtained are shown in Table 1.

Table 1. Variables

\begin{tabular}{l|l|l}
\hline \multicolumn{1}{c|}{ Conceptual Variable } & \multicolumn{1}{|c}{ Indicator } & \multicolumn{1}{c}{ Source of Information } \\
\hline Funding & $\begin{array}{l}\text { Direct fiscal contribution to Traditional } \\
\text { Universities (CRUCH) }\end{array}$ & $\begin{array}{l}\text { Government Funding for Higher Education } \\
\text { 2011(Contraloría General de la República, 2012) }\end{array}$ \\
\hline Quality of Faculty & Number of academics with Ph.D. & Statistical Yearbook 2011 (CRUCH 2012) \\
\hline Ph.D. Graduates & $\begin{array}{l}\text { Number of Ph.D. graduates from } \\
\text { Traditional Universities (CRUCH) }\end{array}$ & Statistical Yearbook 2011(CRUCH 2012) \\
\hline
\end{tabular}

Source: Prepared by the authors

The analysis technique used to process the information from the study is the analysis of multiple linear regressions by the method of successive steps. The equation used is as follows:

$$
\gamma=\beta_{0}+\beta_{1} X_{1}+\beta_{2} X_{2}+\ldots+\beta_{n} X_{n}+e_{i}
$$

Where: $\gamma$ is the dependent variable. The constant $\beta_{0}$ represents the intersection and variables omitted from the model. $\beta_{1}$ to $\beta_{\mathrm{n}}$ represent partial regression coefficients and estimated net linear effect of the variables $X_{1}$ to $X_{n}$, on total and response. Finally, ei refers to the residual error model.

In the case of stepwise regression, the tests of goodness of fit were reviewed, such as the regression coefficient, which shows the explanatory power of the model. The F-test indicates the relevance of the overall statistical model and test $\mathrm{T}$ shows the statistical relevance of the explanatory variables.

\section{RESULTS}

In first instance, it can be set that on average 17 universities that have doctoral graduates in 2012, had an average of $30 \mathrm{Ph}$.D. graduates. Furthermore, universities belonging to $\mathrm{CRUCH}$ have, during that year, an average of 258 academics with doctorates, and on average receive a fiscal contribution of $6,862,720.20(\$ \mathrm{M})$, with a wide variability in the amounts, since the standard deviation is $7349936.049(\$ \mathrm{M})$ as shown in Table 2.

Table 2. Descriptive statistical results

\begin{tabular}{l|c|cc}
\hline & N & Mean & Std. Deviation \\
\hline Direct Fiscal Contribution (DFC) & 25 & $6862720,20 *$ & 7349936,049 \\
\hline Total doctoral graduates by university 2012 & 17 & 30,56 & 41,455 \\
\hline Number of academics with Ph.D. & 25 & 258,48 & 367,631 \\
\hline N valid & 16 & & \\
\hline *(M\$) & & & \\
Source: Prepared by the authors & &
\end{tabular}

At the same time, it should be noted that the number of doctoral graduates of the CRUCH's universities correlates directly, significantly and positively with the Direct Tax Contribution $(R=0.962 ; p<0.001)$ and with the number of academics with Ph.D. $(\mathrm{R}=0.862 ; \mathrm{p}<0.001)$. 
Also is noteworthy that the independent variables are correlated directly with each other (see Table 3 ).

Table 3. Correlation matrix

\begin{tabular}{c|l|c|c}
\hline \multicolumn{2}{l|}{} & Academics with Ph.D. 2012 & Doctoral graduates 2012 \\
\hline \multirow{2}{*}{$\begin{array}{c}\text { Direct Fiscal Contribution } \\
\text { (DFC) } 2012\end{array}$} & Pearson correlation & $.855^{* *}$ & $.929^{* *}$ \\
\cline { 2 - 4 } & Sig. (bilateral) & .000 & .000 \\
\cline { 2 - 4 } & $\mathrm{N}$ & 25 & 16 \\
\hline \multirow{3}{*}{$\begin{array}{c}\text { Academics with Ph.D. 2012 } \\
\end{array}$} & Pearson correlation & & $.923^{* *}$ \\
\cline { 2 - 4 } & Sig. (bilateral) & $\mathrm{N}$ & .000 \\
\cline { 2 - 4 } & $\mathrm{N}$ & & 16 \\
\hline
\end{tabular}

** Correlation is significant at the level 0.01 (bilateral).

Source: Prepared by the authors

Using the regression model of successive steps the following results seen in Table 4 were obtained:

Table 4. Summary of the regression model

\begin{tabular}{c|c|c|c|c|c|c|c|c|c}
\hline \multirow{2}{*}{ Model } & $\mathbf{R}$ & R-square & \multirow{2}{*}{$\begin{array}{c}\text { Adjusted } \\
\text { R-square }\end{array}$} & $\begin{array}{c}\text { Std. Error } \\
\text { of Estimate }\end{array}$ & $\begin{array}{c}\text { R-square } \\
\text { Change }\end{array}$ & F Change & d1 & d2 & $\begin{array}{c}\text { Sig. F } \\
\text { Change }\end{array}$ \\
\hline 1 & $.929^{\mathrm{a}}$ & .863 & .853 & 15.908 & .863 & 87.864 & 1 & 14 & .000 \\
\hline 2 & $.966^{\mathrm{b}}$ & .933 & .923 & 11.504 & .071 & 13.770 & 1 & 13 & .003 \\
\hline
\end{tabular}

a. Predictors: (Constant), DFC; b. Predictors: (Constant), DFC, number of academics with doctorates

b. Dependent variable: Number of Ph.D.'s graduates from universities CRUCH.

Source: Prepared by the authors.

By observing the results of the regression using stepwise was observed the change experienced by R squared at each step, like $\mathrm{F}$ and its significance. In the first model, the value of R-squared is 0.863 . To test the hypothesis that the change in R-squared is zero, a statistic of $87.864 \mathrm{~F}$ is obtained with 1 and 14 degrees of freedom has an associated probability of 0.000 . Since this value is less than 0.05 , it can be established that the proportion of variance explained by the Direct Tax Contribution (independent variable selected in the first step) is significantly different from zero.

In the second step, the value of R-squared increases to 0.933 , implying a change of 0.071 (approximately 7\%). Table 3 shows the value of $\mathrm{F} 13,770$ reached to test the hypothesis that the exchange value of R-square is zero, and its significance $(p<0.05)$. Although the increase is small $(7 \%)$, the value of the critical level made possible that the number of academics with Ph.D.s, built in the second step, contributes significantly to explain what happens with the dependent variable Ph.D.'s graduates. Indeed, the fiscal funding received by the institutions and the number of academics with Ph.D.s they have explained 92\% of the number of Ph.D.'s graduates from the Chilean universities analyzed.

Funding is a key aspect in doctoral training in countries like Norway, where significant changes to the system had been made, as was the introduction of economic incentives in the training of Ph.D.s. In 1993, the Ministry of Education and Research introduced a reimbursement system, through which a specific amount was used to pay to the departments that gave supervision to doctoral candidates, once they obtained their degrees. This agreement had been further developed, and today the number of doctorates awarded is now a factor of entry into the main system of financing of universities (Kyvik and Olsen, 2013).

In this regard, ANOVA's summary table (Table 5) contains the values of F, significant in both steps. 
Table 5. ANOVA ${ }^{\mathrm{a}}$

\begin{tabular}{l|l|r|r|r|r|c}
\hline \multicolumn{1}{c}{ Model } & Sum of squares & df & Mean square & F & Sig. \\
\hline \multirow{2}{*}{1} & Residual regression & 22235.063 & 1 & 22235.063 & 87.864 & $.000^{b}$ \\
\cline { 2 - 7 } & Residual & 3542.874 & 14 & 253.062 & & \\
\cline { 2 - 7 } & Total & 25777.937 & 15 & & & $.000^{\mathrm{c}}$ \\
\hline \multirow{2}{*}{2} & Residual regression & 24057.444 & 2 & 12028.722 & 90.889 & \\
\cline { 2 - 7 } & Residual & 1720.493 & 13 & & & \\
\cline { 2 - 8 } & Total & 25777.937 & 15 & & & \\
\hline
\end{tabular}

a. Dependent variable: Graduate of doctoral programs 2012 b. Predictors: (Constant), DFC 2012 c. Predictors: (Constant), DFC 2012, Academics with Ph.D. 2012.

Source: Prepared by the authors.

By analyzing the coefficients of partial regression of the variables included in the regression model stepwise, the values of $\mathrm{t}$ in Table 6 show the individual contributions of the variables, Direct Fiscal Contribution and Academic $\mathrm{Ph} . \mathrm{D}$., are significant $(\mathrm{p}<0.05)$, therefore you can set both variables contribute significantly to improving the quality of the regression model.

In this regard, it should be noted that there has been an increase in research evaluation, where academics are measured according to the quality and productivity of their research, which has an effect on doctoral students who are motivated to publishing articles while studying for their Ph.D.s, in order to gain a competitive edge when applying for academic positions (Sharmini et al., 2014). Indeed, the quality of faculty and hence their work has an impact on students in doctoral programs.

Table 6. Coefficients ${ }^{\mathrm{a}}$ of the regression model

\begin{tabular}{|c|c|c|c|c|c|c|}
\hline & \multirow[t]{2}{*}{ Model } & \multicolumn{2}{|c|}{ Unstandardized coefficients } & \multirow{2}{*}{$\begin{array}{c}\begin{array}{c}\text { Standardized } \\
\text { coefficients }\end{array} \\
\text { Beta }\end{array}$} & \multirow[t]{2}{*}{$\mathbf{t}$} & \multirow[t]{2}{*}{ Sig. } \\
\hline & & B & Beta & & & \\
\hline \multirow{2}{*}{1} & (Constant) & -13.696 & 6.173 & & -2.219 & .044 \\
\hline & DFC 2012 & $4.730 \mathrm{E}-006$ & .000 & .929 & 9.374 & .000 \\
\hline \multirow{3}{*}{2} & (Constant) & -11.325 & 4.510 & & -2.511 & .026 \\
\hline & DFC 2012 & 2.654E-006 & .000 & .521 & 3.974 & .002 \\
\hline & Ph.D. academics 2012 & .047 & .013 & .487 & 3.711 & .003 \\
\hline
\end{tabular}

a. Dependent variable: Graduate of doctoral programs 2012.

Source: Prepared by the authors.

In Table 7, is possible to observe the variables that were not considered to be part of the regression equation in step 1. In the first step, the variable considered was the Direct Fiscal Contribution received by the institutions of higher education analyzed, because it is most correlated, in absolute value, with the dependent variable graduates of doctoral programs.

Table 7. Excluded Variables ${ }^{\mathrm{a}}$

\begin{tabular}{|c|c|c|c|c|c|c|}
\hline \multicolumn{2}{|r|}{ Model } & Beta within & $\mathbf{t}$ & Sig. & Partial Correlation & $\begin{array}{c}\text { Collinearity statistics } \\
\text { tolerance }\end{array}$ \\
\hline 1 & Academics with Ph.D. 2012 & $.487^{\mathrm{b}}$ & 3.711 & .003 & .717 & .298 \\
\hline
\end{tabular}

a. Dependent variable: Graduate of doctoral programs 2012 b. (Constant), AFD2012: predictor variables in the model.

Source: Prepared by the authors.

Indeed, doctoral education is a central element in the traditional identity of a university. In most countries, only universities may award the degree of Doctor. Thus, it has invested heavily in the university staff in this area.

In this respect, it stands as an example, the case of Norway, where the idea of doctoral programs comes from an evaluation carried out in 2002. As a result, many colleges, faculties, and other units have reacted by requesting their faculties to generate doctoral programs. In some cases, these requests have been accompanied by financial incentives (Nyhagen and Baschung, 2013). 


\section{CONCLUSIONS}

The research results reveal the importance of the quality of faculty in the process of formation of Ph.D.s, because it impacts the training and graduation process, in the sense of being relevant aspects such as publication in scientific journals. Therefore, this is a key factor because the generation of advanced human resources through training of Ph.D.s is one of the most important roles in higher education institutions.

Moreover, it can be established, according to the results analyzed, that the fiscal funding received by institutions of higher education has a significant impact on the training of Ph.D.s. This is very important, since in the case of universities analyzed, $5 \%$ of funding was associated with annual performance indicators such as student enrollment, number of academics with postgraduate studies and the number of projects and publications of excellence research. Indeed, institutions that receive more resources are those with, among other things, a high-quality faculty, which eventually affects the training of doctors in these colleges. Therefore, the Direct Fiscal Contribution plays an important role as the catalyst for the formation processes in these institutions.

Therefore, about the results obtained in this investigation, the fiscal funding and the quality of faculty, impact directly on the training of Ph.D.s in Chile. Consequently, institutions of higher education that have greater financial resources, have a higher quality faculty, and consequently achieve a greater number of Ph.D. graduates in their institutions of higher education.

\section{ACKNOWLEDGEMENTS}

This work is sponsored by CONICYT through funding of FONDECYT 1140026 Project and has the support of the Center for Studies of the University of Tarapacá, CEUTA.

\section{AUTHOR BIOGRAPHIES}

Liliana Pedraja Rejas has a Ph.D. and Masters in Educational Sciences from Pontificia Universidad Católica de Chile. She also has a Ph.D. in Business Administration and a Master in Marketing \& Management, Universidad Politécnica de Valencia, Spain. She is professor and director of the Research Center CEUTA from the University of Tarapacá, Chile. She is a senior researcher of significant projects and has several academic publications in specialized journals about higher education and leadership. Email: lpedraja@uta.cl; Address: Centro de Estudios CEUTA - Universidad de Tarapacá. Casilla 7-D. Arica, Chile.

Emilio Rodríguez Ponce has a Ph.D. and Masters in Education from Universidad Autónoma de Barcelona. He also has a Ph.D. in Economic and Business Sciences, Universidad Complutense de Madrid. He is professor at the University of Tarapacá, Chile. He has a valuable career in management of higher education institutions, and has participated in directories from public and private organizations as President, Vice President and Director. He was the first president of the Comisión Nacional de Acreditación of Chile and two times President/Rector of the University of Tarapacá. He is a senior researcher, author and editor of books, chapters and publications. Email: emilior.rodriguez.ponce@gmail.com; Address: Instituto de Alta Investigación - Universidad de Tarapacá. Casilla 7-D. Arica, Chile.

Carmen Araneda Guirriman is a Sociologist and has a Masters in Social Investigation and Development from Universidad de Concepción. She is academic at the University of Tarapacá, Chile. Email: caraneda@uta.cl; Address: Centro de Estudios CEUTA - Universidad de Tarapacá. Casilla 7-D. Arica, Chile.

\section{REFERENCES}

Alexander, F. K. (2000). The changing face of accountability: Monitoring and assessing institutional performance in higher education. Journal of Higher Education, 71(4), 411-431.

Al-Ghamdi, S., \& Malcolm, M. (2013). Selecting and Developing High-Quality Academic Staff. Higher Education Dynamics, 30, 83-93.

Araneda-Guirriman, C., Rodríguez-Ponce, E., \& Pedraja-Rejas, L. (2013). Relación entre el Financiamiento Fiscal, la Calidad del Cuerpo Académico y la Retención de Estudiantes Universitarios en Chile. Formación universitaria, 6(6), 55-64.

Copyright by author(s); CC-BY 
Austin, A. E. (2002). Preparing the next generation of faculty: Graduate school as socialization to the academic career. The Journal of Higher Education, 73(1), 94-122.

Barr, N. (1993). Alternative funding resources for higher education. The Economic Journal, 103(418), 718-728.

Bernasconi, A. (2014). Policy path dependence of a research agenda: the case of Chile in the aftermath of the student revolt of 2011. Studies in Higher Education, 39(8), 1405-1416.

Chen, C. Y., Chen, P. C., \& Chen, P. (2014). Teaching quality in higher education: An introductory review on a process-oriented teaching-quality model. Total Quality Management \& Business Excellence, 25(1), 36-56.

Craswell, G. (2007). Deconstructing the skills training debate in doctoral education. Higher Education Research \& Development, 26(4), 377-391.

Contraloría General de la República (2012). Financiamiento Fiscal a la Educación Superior 2011. Contraloría General de la República División de Análisis Contable Área Empresas Públicas y Universidades.

CRUCH, Anuario estadístico (2011). Santiago de Chile.

DIVESUP (2013). Aporte Fiscal Directo. http://www.divesup.cl/index2.php?id_portal=38\&id_seccion=3063\&id_contenido=12222 Fecha de Acceso: 25 November 2014.

Dobson, I. R. (2012). PhDs in Australia, from the beginning. Australian Universities' Review. 54(1), 94 - 101.

Doran, M. R., \& Lott, W. B. (2012). A duty of care. Trends in biochemical sciences, 38(1), 1-2.

Edwards, D., \& Smith, T. F. (2010). Supply issues for science academics in Australia: now and in the future. Higher Education, 60(1), 19-32.

Enders, J. (2005). Border crossings: Research training, knowledge dissemination and the transformation of academic work. Higher Education, 49(1), 119-133.

Freeman, R. B. (2010). What Does Global Expansion of Higher Education Mean for the United States?. American Universities in a global market, pp. 373-404. University of Chicago Press.

Gunawardena, C. (2013). A Constructivist Approach Towards Quality Development in Universities: An Issue of Quality in Sri Lankan Universities. Sri Lanka Journal of Advanced Social Studies, 2(2), 05-21.

Halse, C., \& Mowbray, S. (2011). The impact of the doctorate. Studies in higher education, 36(5), 513-525.

Harman, G. (2002). Producing PhD graduates in Australia for the knowledge economy. Higher Education Research and Development, 21(2), 179-190.

Hax, A., \& Ugarte, J. (2014). Hacia la Gran Universidad Chilena: Un modelo de transformación estratégica. Santiago: Ediciones $\mathrm{UC}, 296 \mathrm{p}$.

Heaney, R., Evans, T., Macauley, P., \& Pearson, M. (2012). The impact of Australian higher education policy changes on the production of PhDs in the field of accounting and finance. Accounting \& Finance, 53(3), 691-710.

Herman, C. (2011). Expanding doctoral education in South Africa: pipeline or pipedream? Higher Education Research \& Development, 30(4), 505-517.

Kehm, B. M. (2009). New forms of doctoral education and training in the European higher education area. The European higher education area: Perspectives on a moving target. Rotterdam: Sense Publisher.

Kyvik, S., \& Olsen, T. B. (2013). Increasing completion rates in Norwegian doctoral training: multiple causes for efficiency improvements. Studies in Higher Education, 39(9), 1668-1682.

Lavonen, J., \& Krzywacki, H. (2014). Recent trends in PhD education in mathematics and science education research: back to university level organization. Nordic Studies in Science Education, 10(2), 243-250.

Liu, Z., \& Geng, Y. (2011). Is China producing too many PhDs? Nature, 474(7352), 450-450.

Lorange, P. (2006). A performance-based, minimalist human resource management approach in business schools. Human Resource Management, 45(4), 649-658.

Manathunga, C., Pitt, R., \& Critchley, C. (2009). Graduate attribute development and employment outcomes: tracking PhD graduates. Assessment \& Evaluation in Higher Education, 34(1), 91-103.

Marginson, S. (2013). The impossibility of capitalist markets in higher education. Journal of Education Policy, 28(3), 353-370.

Nerad, M. (2010). Increase in PhD production and reform of doctoral education worldwide. Research Institute for Higher Education Hiroshima University, 7, 69 -84.

Nyhagen, G. M., \& Baschung, L. (2013). New organisational structures and the transformation of academic work. Higher Education, 66(4), 409-423.

Neumann, R., \& Tan, K. K. (2011). From PhD to initial employment: the doctorate in a knowledge economy. Studies in Higher Education, 36(5), 601-614.

OCD (2013). Education at a Glance 2013 OECD indicators.

OCDE (2009). La educación superior en Chile. Revisión de políticas nacionales de educación. OCDE y el Banco Internacional para la Reconstrucción y el Desarrollo.

Pedraja-Rejas, L., \& Rodríguez-Ponce, E. (2015). Dirección estratégica y gestión en instituciones de educación superior. En A. Bernasconi La Educación Superior de Chile: Transformación, Desarrollo y Crisis (pp. 475-516). Santiago: Ediciones UC.

Perkmann, M., King, Z., \& Pavelin, S. (2011). Engaging excellence? Effects of faculty quality on university engagement with industry. Research Policy, 40(4), 539-552. 
Schubert, T., Bonaccorsi, A., Brandt, T., De Filippo, D., Lepori, B., Niederl, A., Schmoch, U., \& Slipersaeter, S. (2014). Is there a European university model? New evidence on national path dependence and structural conver-gence. In A.

Bonaccorsi (Ed.) Knowledge, Diversity and Performance in European Higher Education: A Changing Landscape, 47 pp.

Sharmini, S., Spronken-Smith, R., Golding, C., \& Harland, T. (2014) . Assessing the doctoral thesis when it includes published work. Assessment \& Evaluation in Higher Education, (ahead-of-print), 1-14.

Schneider, P., \& Sadowski, D. (2010). The impact of new public management instruments on PhD education. Higher Education, 59(5), 543-565.

SIES (2014). Compendio Histórico de Educación Superior. Ministerio de Educación.

Thorn, K. (2005). Chile: Higher Education Improvement Project. In Implementation Completion Report, No. 34617. Washington, DC: World Bank.

Udam, M., \& Heidmets, M. (2013). Conflicting views on quality: interpretations of 'a good university' by representatives of the state, the market and academia. Quality in Higher Education, 19(2), 210-224.

Varga, A. \& Horváth, M. (2014). Institutional and Regional Factors Behind University Patenting in Europe: An Exploratory Spatial Analysis Using EUMIDA Data. Regional Growth, Competitiveness and Development, 143-167.

Vera-Villarroel, P. (2010). Historia y estado actual de la formación doctoral en Chile. Revista Digital Universitaria, 11(5), 1-17.

Waldinger, F. (2010). Quality matters: The expulsion of professors and the consequences for PhD student outcomes in Nazi Germany. Journal of Political Economy, 118(4), 787-831. 